\section{Hyötytietoa yliopistopedagogiikasta}

Murtonen, Mari (toim.) (2017). Opettajana yliopistolla. Vastapaino. 425 sivua.

ERIKOISTUTKIJA ja yliopistopedagogiikan dosentti Mari Murtonen Turun yliopistosta on toimittanut ajankohtaiseen tutkimukseen perustuvan korkeakoulupedagogiikan kirjan. Muut kirjoittajat ovat Turun yliopiston opettajia ja tutkijoita.

Opettajana yliopistolla on nimensä mukaisesti suunnattu yliopiston opettajille. On arvokasta, että Murtonen on koonnut tietoa oppimisesta ja opettamisesta korkeakouluissa. Edellinen alan perusteos, kertaalleen jo päivitetty Sari Lindblom-Ylänteen ja Anne Nevgin toimittama Yliopisto-opettajan käsikirja on vuodelta 2009. Teos on tärkeä, koska enää ei voi olla vakavasti otettava yliopiston opettaja, jos perustaa opetusajattelunsa ja -taitonsa pelkästään oman alansa opetuksen traditioihin ja mallioppimiseen.

Tutkimukseen perustuva opetus yliopistossa tarkoittaakin sitä, että opetettavan sisällön lisäksi se, miten opetus järjestetään ja miten opetetaan, perustuu tutkimustietoon oppimisesta ja opettamisesta.

Vaikka kirjassa useaan kertaan tuodaan esiin, että oppiminen on monimutkainen prosessi, kirjoittajat onnistuvat avaamaan oppimista koskevaa tutkimusta siten, että yliopisto-opettaja pystyy sitä hyödyntämään. Teoksessa on myönteinen, sekä opiskelijan että opettajan taitojen kehittymiseen luottava tunnelma. Tällainen kasvun asenne on tullut tunnetuksi Stanfordin yliopiston professori Carol Dweckin tutkimusten myötä, ja tällaisen asenteen on havaittu edistävän oppimista.

\section{OPETTAJA AUTTAA TIEDON RAKENTAMISESSA}

Kirja on jaettu kolmeen osaan: tavoitteena oppiminen ja asiantuntijuus, opettaminen taitona sekä yliopisto toimintaympäristönä. Ensimmäisessä osassa avataan muun muassa asiantuntijan oppimista ja käsitteellistä muutosta koskevaa tutkimusta. Murtonen perustelee, miksi opettajaa tarvitaan konstruktivistiseen oppimisteoriaan nojautuvassa opetuksessa. Vaikka tieto ei sellaisenaan siirry opettajan päästä puheen välityksellä opiskelijalle, opettaja voi opetuksen ja oppimateriaalin organisoinnin kautta vaikuttaa opiskelijan tiedon rakentamiseen. Tämä tilaisuus opettajan kannattaa käyttää hyväksi!

Opettajan toiminnan kannalta hyödyllisiä käsitteitä ovat myös Mirjamaija Mikkilä-Erdmanin esittelemä 'metakäsitteellinen tietoisuus' ja Tuike Iiskalan esiin tuoma 'sosiaalisesti jaettu metakognitio' ja 'oppimisen yhteissäätely'. Vaikka ryhmien

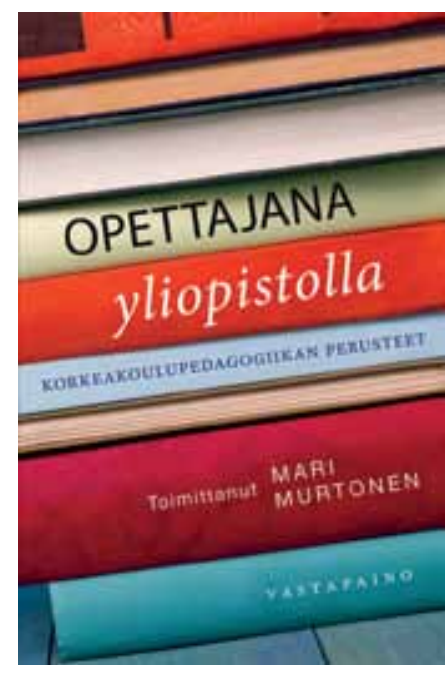

merkityksestä oppimiselle ei ole omaa lukua, Iiskalan esimerkit yhteissäätelystä antavat työvälineitä opettajalle, joka miettii opiskelijaryhmien käyttöä opetuksessaan.

\section{RESURSSI EI MAHDOLLISTA IDEAALIA}

Toisessa osassa Murtonen esittelee "Opettaminen ja opetuksen suunnittelu taitona" -artikkelissaan selkeän mallin, joka on käytännöllisempi kuin esimerkiksi John Biggsin ja Catherine Tangin (2007) linjakkaan opetuksen malli ja tuo esiin resurssien vaikutuksen opetus- ja oppimisympäristön suunnitteluun. Juuri rajalliset resurssit aiheuttavat innokkaissa ja kunnianhimoisissa opetuksen kehittäjissä tuskaa. Opettajat ovat yliopistopedagogiikan opintojen myötä alkaneet ymmärtää, mistä tekijöistä hyvä opetus koostuu. Opetukseen käytettävä resurssi vain ei mahdollista ideaalimallin toteutusta. 
Lisäksi Murtonen käsittelee lyhyesti, miten erilaiset opetusmenetelmät edistävät oppimista. Hän perustelee, minkälaisiin tilanteisiin luento sopii ja minkälaisiin aktivoiviin opetusmenetelmiin sen voi yhdistää. Luennosta ei siis tarvitse kokonaan luopua, vaan se jatkaa elinvoimaisena, mutta muuttuneessa muodossa.

Mari Murtonen, Timo Halttunen, Matti Lappalainen ja Riitta Pyykkö avaavat niin sanottuun Bolognan prosessiin liittyvää osaamisperustaisuutta artikkelissaan "Osaamistavoitteet ja opetuksen suunnittelu". He pohtivat osaamisperustaisuuden haasteita ja kannattavat osaamisperustaisuutta sovellettaessa oppimisen prosessiluonteen painottamista sekä yhteistyötä opiskelijoiden kanssa.

\section{KOLLEGIAALINEN YHTEISTYÖ VAHVISTUU}

Kolmannessa osassa pohditaan, minkälaisen toimintaympäristön yliopisto tarjoaa opettajalle. Anne Laiho, Annukka Jauhiainen ja Arto Jauhiainen tuovat esille sen, että yliopisto-opettajan melko suuren autonomian kääntöpuolena on vähäinen kollegiaalinen yhteistyö. Uskon, että tämä kylläkin muuttuu monessa suomalaisessa yliopistossa toteutettujen isojen opetussuunnitelmauudistusten myötä, ja edessä ovat yhteistyön haasteet. Vahvojen ja autonomisten henkilöiden muodostaman yliopistoyhteisön johtaminen on Riitta Pyykön ja Matti Lappalaisen mukaan vaativaa. Artikkelissaan "Koulutuksen johtaminen muuttuvassa yliopistomaailmassa" he tarjoavat avuksi avointen ja dynaamisten systeemien paradigmaa ja jaettua pedagogista johtamista.

\section{UUSIN TUTKIMUS VAIHTELEVASTI MUKANA}

Artikkelien laatu vaihtelee. Useimmista tuodaan esiin tuoreinta tieteellistä tutkimusta erityisesti niiltä aloilta, joissa Turun yliopiston tutkijat ovat ansioituneet. Toisenlaisiakin artikkeleita on mukana. Esimerkiksi Riitta Koskimiehen artikkelissa "Opettajan viestintäja vuorovaikutusosaaminen" kaipaisi vielä vahvemmin uusimman tutkimuksen esittelyä.

Lähes kaikissa artikkeleissa kirjoittajat onnistuvat avaamaan tutkimustietoa opettajan näkökulmasta. Parhaimmillaan oppimisen ja opettamisen käsitteet muuntuvat työkaluiksi yliopistoopetuksen suunnitteluun ja toteutukseen.

Kirja kattaa monia kansainvälisestikin keskeisiä yliopistopedagogiikan tutkimuskohteita. Paljon kiinnostavaa tietenkin rajautuu pois, esimerkiksi tunteet osana niin opettajan kuin opiskelijan työtä sekä oppineisuus yliopistoopetuksessa (Scholarship of Teaching and Learning).

Opettajana yliopistolla soveltuu johdatukseksi kaikkien alojen yliopisto-opettajille. Aiheesta kiinnostuvan opettajan kannattaa tutustua myös oman alansa korkeakouluoppimista ja -opettamista koskevaan tutkimukseen. Monilla aloilla, kuten lääketieteessä, on omat julkaisunsa ja kongressinsa, joissa keskitytään tietyn alan erityiskysymyksiin.

\section{SAARA REPO}

FT, VTL, pedagoginen yliopistonlehtori Helsingin yliopisto

\section{LÄHTEET}

Biggs, J. \& Tang, C. (2007) Teaching for Quality Learning at University. The Society for Research into Higher Education \& Open University Press. 3rd edition.

Dweck, C. S. (2012). Mindset: How You Can Fulfill Your Potential. Constable \& Robinson Limited. Lindblom-Ylänne S. \& Nevgi A. (toim.) (2009). Yliopisto-opettajan käsikirja. WSOYpro. 